UDC 342.743

LBC 67.9(4Укр) 300

\title{
CONSTITUTIONAL LAW PROBLEMS OF THE LEGAL REGULATION OF THE PROCEDURE FOR LEVYING ENVIRONMENTAL PAYMENTS
}

\author{
Aleksey V. Ushakov \\ Academy of General Prosecutor of Russian Federation, Volgograd, Russian Federation
}

Introduction: the article is devoted to the problems related to the constitutional law regulation of the procedure for levying payments for environmental pollution. For this purpose, the author studies the problems associated with the imperfection of the legal regulation of the procedure for levying "environmental payments" in Russia. By applying the scientific methods, primarily the method of system analysis of judicial and regulatory legal acts, the author comes to the necessity of improving the legal regulation in the sphere of levying payments for the negative impact on the environment. Results: the author highlights a number of contentious issues in determining the procedure of levying environmental payments.

Conclusions: according to the author, the introduction of "environmental payment" fixed by Federal Law will allow raising the constitutional level of its statutory regulation, obtaining additional funds for the implementation of the state policy in the field of environmental protection.

Key words: environmental management, payment for negative impact on environment, revenue charges, Constitutional Court of Russian Federation, legal proposition, environmental payment.

УДК 342.743

ББК 67.9(4Укр)300

\section{КОНСТИТУЦИОННО-ПРАВОВЫЕ ПРОБЛЕМЫ ПРАВОВОГО РЕГУЛИРОВАНИЯ ПОРЯДКА ВЗИМАНИЯ ЭКОЛОГИЧЕСКИХ ПЛАТЕЖЕЙ}

\author{
Алексей Викторович Ушаков \\ Академия Генеральной прокуратуры РФ, г. Волгоград, Российская Федерация
}

\begin{abstract}
Введение: статья посвящена выявлению проблем, связанных с конституционно-правовым регулированием порядка взимания платежей за загрязнение окружающей природной среды. С этой целью автор изучает проблемы, связанные с несовершенством правового регулирования порядка взимания «экологических платежей» в России. С помощью методов научного познания, в первую очередь метода системного анализа судебных и нормативно-правовых актов, автор приходит к необходимости совершенствования правового регулирования в сфере взимания платежей за негативное воздействие на окружающую природную среду. Результаты: автором указывается на наличие ряда спорных вопросов при определении порядка взимания «экологических платежей».

Выводы: по мнению автора, введение определенного федеральным законом «экологического платежа» позволит поднять конституционно-правовой уровень его нормативного регулирования, получить дополнительные средства для реализации государственной политики в области охраны окружающей среды.

Ключевые слова: природопользование, платеж за негативное воздействие на окружающую природную среду, фискальный сбор, Конституционный суд РФ, правовая позиция, экологический платеж.
\end{abstract}

\section{Введение}

Платность природопользования является основой экономического механизма охра- ны окружающей природной среды и одним из источников финансирования экологических программ. На сегодняшний день во многих странах мира введены налоги за загрязнение 


\section{ПРАВОВЫЕ ПРОБЛЕМЫ ОХРАНЫ ОКРУЖАЮЩЕЙ СРЕДЫ}

окружающей среды (Франция, Финляндия, Дания, Норвегия), многие государства мира берут курс на «очищение» $[1$, с. 130]. Не является исключением и Россия. Совокупность гарантированных Конституцией РФ социально-экономических прав человека, к которым мы относим и право на благоприятную природную среду, обеспечивает возможность реализации материальных потребностей личности при одновременном предоставлении гарантий на достойные условия жизни граждан России.

\section{Нормативно-правовое регулирование порядка уплаты платежей} за негативное воздействие на окружающую природную среду

Согласно ч. 1 ст. 7 Конституции РФ социальное государство призвано заботиться о создании условий, обеспечивающих достойную жизнь и свободное развитие человека.

На основании нормы, закрепленной в ч. 1 ст. 34 Федерального закона от 10.01.2002 № 7-Ф3 «Об охране окружающей среды», размещение, проектирование, строительство, реконструкция, ввод в эксплуатацию, эксплуатация, консервация и ликвидация зданий, строений, сооружений и иных объектов, оказывающих прямое или косвенное негативное воздействие на окружающую среду, осуществляются в соответствии с требованиями в области охраны окружающей среды [4]. Согласно ч. 1 ст. 16 указанного Федерального закона негативное воздействие на окружающую среду является платным, причем плату за загрязнение окружающей среды часто еще называют «экологическим платежом». Как определено п. 3 ст. 16 Закона № 7-Ф3, порядок исчисления и взимания платы за негативное воздействие на окружающую среду устанавливается законодательством Российской Федерации. Однако до настоящего времени этот порядок федеральным законом не установлен, и при определении платы правоприменитель руководствуется следующими нормативными документами:

- Постановление Правительства РФ от 03.03.2017 № 255 «Об исчислении и взимании платы за негативное воздействие на окружающую среду» [4].
- Постановление Правительства РФ от 13.09.2016 № 913 «О ставках платы за негативное воздействие на окружающую среду и дополнительных коэффициентах» [3].

\section{Проблемы нормативного регулирования порядка взимания платежей}

Однако, как показывает проведенный анализ судебной практики, вопросы, касающиеся полноты и своевременности внесения платы за негативное воздействие на окружающую среду, вызывают многочисленные споры. Вопрос о законности введения природоохранных платежей неоднократно рассматривался высшими судебными инстанциями, причем одному и тому же правовому акту давалась различная правовая оценка. До 2002 г. плата за нормативные и сверхнормативные выбросы и сбросы загрязняющих веществ администрировалась налоговыми органами, которые в свою очередь настаивали, что указанные платежи по своей правовой природе являются налоговыми платежами и обладают всеми признаками, предусмотренными ст. 8 НК РФ. Вместе с тем все существенные элементы платы были определены Постановлением Правительства РФ, а также разъяснениями министерств и ведомств, которые не только не публиковались для всеобщего сведения, но и не были зарегистрированы в Минюсте России. Верховным судом РФ при рассмотрении заявления заинтересованных лиц было принято решение от 28 марта 2002 г. № ГКПИ 2002178 «О признании незаконным (недействительным) Постановления Правительства Российской Федерации от 28 августа 1992 г. № 632 “Об утверждении Порядка определения платы и ее предельных размеров за загрязнение окружающей природной среды, размещение отходов, другие виды вредного воздействия"». Однако затем вопросы, связанные с применением законодательства об установлении платы за негативное воздействие на окружающую природную среду, стали предметом рассмотрения Конституционного суда РФ. В своем Определении от 10 декабря 2002 г. № 284-0 «По запросу Правительства Российской Федерации о проверке конституционности Постановления Правительства Российской Федерации “Об утверждении Порядка опре- 
деления платы...”» Конституционный суд РФ признал плату за загрязнение окружающей природной среды фискальным сбором неналогового характера, а постановление Правительства РФ от 28.08.2001 № 632 - действующим, а равно признал право на установление всех элементов этой платы не только федеральным законом, но и подзаконным актом. В настоящее время порядок определения платы (и ее предельные размеры) за загрязнение окружающей природной среды, размещение отходов и другие виды вредного воздействия регламентирован рядом подзаконных актов. Приведенные выше Постановления Правительства РФ в разные периоды времени определяли лишь размер платежей. Между тем законодательных норм, которые наделяли бы Правительство РФ правом устанавливать плату за негативное воздействие на окружающую среду, федеральное законодательство не содержало и не содержит.

Таким образом, многие существенные вопросы исчисления и перечисления в бюджет платы за загрязнение окружающей среды законодательно не установлены, при решении этих вопросов правоприменитель руководствуется рекомендациями территориальных органов МПР РФ, не имеющими нормативного характера. При этом ответ на вопрос, отвечает ли правовое регулирование платежей за загрязнение окружающей природной среды требованиям Конституции РФ и Налоговому кодексу РФ, остается открытым. Вместе с тем, по мнению автора, существенные элементы указанного платежа федеральным законом не определены. Это такие элементы, как: объект налогообложения, налоговая ставка, срок уплаты и отчетный период, льготы по уплате платежей. Понижающие и повышающие коэффициенты определены подзаконными правовыми актами (постановления, приказы, инструктивно-методические указания и т. п.), что недопустимо.

\section{Выводы}

Исходя из приведенного анализа правовых актов, судебных актов Верховного суда РФ и Конституционного суда РФ, полагаем, что с течением времени назрела необходимость совершенствования законодательства, регулирующего систему «экологических платежей». Этому будет способствовать принятие следующих мер: а) придание платежам правового статуса налога или обязательного сбора; б) усовершенствование механизма индексации базовых ставок в соответствии с прогнозируемым уровнем инфляции, что будет также носить социально-экономическую направленность; в) четкое определение круга плательщиков, объектов налогообложения, льгот, предусмотренных для определенных категорий плательщиков, порядок установления ставок, повышающих и понижающих коэффициентов.

Введение определенного федеральным законом «экологического платежа», по нашему мнению, позволит поднять конституционно-правовой уровень его нормативного регулирования, получить дополнительные средства для реализации государственной политики в области охраны окружающей среды.

\section{СПИСОК ЛИТЕРАТУРЫ}

1. Гражданкина, О. А. Экологические налоги в странах Европейского Союза // Вестник Государственного аграрного университета. - 2013. - № 6 .

2. Конституция Российской Федерации (принята всенародным голосованием 12.12.1993) (с учетом поправок, внесенных Законами РФ о поправках к Конституции РФ от 30.12.2008 № 6-ФКЗ, от 30.12.2008 № 7-ФКЗ) // Собрание законодательства РФ. - 2009. - № 4. - Ст. 445.

3. Постановление Правительства РФ «О ставках платы за негативное воздействие на окружающую среду и дополнительных коэффициентах» от 13 сент. 2016 г. № 913 // Собрание законодательства РФ. - 2016. - № 38. - Ст. 5560.

4. Постановление Правительства РФ «Об исчислении и взимании платы за негативное воздействие на окружающую среду» от 3 марта 2017 г. № 255 // Собрание законодательства РФ. - 2017. № 11. - Ст. 1572.

5. Федеральный закон «Об охране окружающей среды» от 10 янв. 2002 г. № 7-ФЗ : (в ред. от 3 июля 2016 г.) // Российская газета. $-2012 .-12$ февраля. - № 6 .

\section{REFERENCES}

1. Grazhdankina O.A. Ekologicheskie nalogi v stranakh Evropeyskogo Soyuza [Ecological Taxes in 


\section{ПРАВОВЫЕ ПРОБЛЕМЫ ОХРАНЫ ОКРУЖАЮЩЕЙ СРЕДЫ}

the EU Countries]. Vestnik Gosudarstvennogo agrarnogo universiteta, 2013, no. 6.

2. Konstitutsiya Rossiyskoy Federatsii (prinyata vsenarodnym golosovaniem 12.12.1993) (s uchetom popravok, vnesennykh Zakonami RF o popravkakh $\mathrm{k}$ Konstitutsii RF ot 30.12.2008 № 6-FKZ, ot 30.12.2008 № 7-FKZ) [The Constitution of the Russian Federation (Adopted by the Popular Voting on December 12, 1993 (with Amendments by Laws of the Russian Federation on Amendments in the Constitution of the Russian Federation of December 30, 2008 no. 6-FKL, no. 7-FKL)]. Sobranie zakonodatelstva RF, 2009, no. 4, art. 445.

3. Postanovlenie Pravitelstva RF «O stavkakh platy za negativnoe vozdeystvie na okruzhayushchuyu sredu i dopolnitelnykh koeffitsientakh» ot 13 sent. 2016 g. № 913 [Resolution of the Government of the Russian Federation “On Payment Rates for the Negative Impact on the Environment and Additional Coefficients" of September 13, 2016 no. 913]. Sobranie zakonodatelstva $R F, 2016$, no. 38, art. 5560 .

4. Postanovlenie Pravitelstva $\mathrm{RF} \ll \mathrm{Ob}$ ischislenii i vzimanii platy za negativnoe vozdeystvie na okruzhayushchuyu sredu» ot 3 marta 2017 g. № 255 [Resolution of the Government of the Russian Federation " On Calculation and Collection of Fees for the Negative Impact on the Environment" of March 3, 2017 no. 255]. Sobranie zakonodatelstva RF, 2017, no. 11 , art. 1572 .

5. Federalnyy zakon «Ob okhrane okruzhayushchey sredy» ot 10 yanv. $2002 \mathrm{~g}$. № 7-FZ: (v red. ot 3 iyulya 2016 g.) [Federal Law “On Environmental Protection" of January 10, 2002 no. 7-FL: (amend. of July 3, 2016)]. Rossiyskaya gazeta, 2012, February 12, no. 6.

\section{Information about the Author}

Aleksey V. Ushakov, Prosecutor of the Voroshilovsky District of Volgograd, Candidate for a Degree, Academy of General Prosecutor of Russian Federation, Barrikadnaya St., 23, 400074 Volgograd, Russian Federation, ushakov_alex@mail.ru.

\section{Информация об авторе}

Алексей Викторович Ушаков, прокурор Ворошиловского района г. Волгограда, соискатель, Академия Генеральной прокуратуры РФ, ул. Баррикадная, 23, 400074 г. Волгоград, Российская Федерация, ushakov_alex@mail.ru. 